\title{
Syntheses and reactivity of molybdenum complexes containing the diphenylphosphinodithioformato ligand
}

\author{
Kuang-Hway Yih ${ }^{\text {a, }}$ Ying-Chih Lin ${ }^{\mathrm{b}, *}$ \\ a Department of Applied Cosmetology, Hung Kuang Institute of Technology, Sahlu, Taichung, Taiwan 433, Taiwan, ROC \\ ${ }^{\mathrm{b}}$ Department of Chemistry, National Taiwan University, Taipei, Taiwan 106, Taiwan, ROC
}

Received 3 August 1998; received in revised form 12 October 1998

\begin{abstract}
Treatment of $\left[\mathrm{Et}_{4} \mathrm{~N}\right]\left[\mathrm{Mo}(\mathrm{CO}) 5\left(\mathrm{PPh}_{2}\right)\right](\mathbf{1})$ with $\mathrm{CS}_{2}$ afforded $\left[\mathrm{Et}_{4} \mathrm{~N}\right]\left[\mathrm{Mo}(\mathrm{CO})_{5}\left(\mathrm{PPh}_{2} \mathrm{CS}_{2}\right)\right](\mathbf{3})$ which was also synthesized from the reaction of $\mathrm{Mo}(\mathrm{CO})_{5}\left(\mathrm{CH}_{3} \mathrm{CN}\right)$ with $\left[\mathrm{Et}_{4} \mathrm{~N}\right]\left[\mathrm{PPh}_{2} \mathrm{CS}_{2}\right]$ (2). In complex 3, the diphenylphosphinodithioformato ligand, $\mathrm{PPh}_{2} \mathrm{CS}_{2}^{-}$, coordinated to the molybdenum through the phosphorus atom. The reactions of $\mathbf{3}$ with various alkyl halides yielded the neutral complexes $\mathrm{Mo}(\mathrm{CO})_{5}\left[\mathrm{PPh}_{2}\left(\mathrm{CS}_{2} \mathrm{R}\right)\right]\left(\mathrm{R}=\mathrm{C}_{2} \mathrm{H}_{5}, \mathrm{C}_{2} \mathrm{H}_{4} \mathrm{OH}, \mathrm{C}_{3} \mathrm{H}_{5}, 4-6\right)$. Acylation of 3 with 1-naphthoyl chloride $\left[\mathrm{C}_{10} \mathrm{H}_{7} \mathrm{C}(\mathrm{O}) \mathrm{Cl}\right]$ gave the complex $\mathrm{Mo}(\mathrm{CO})_{5}\left[\mathrm{PPh}_{2}\left(\mathrm{CS}_{2} \mathrm{COC}_{10} \mathrm{H}_{7}\right)\right]$ (7) with moderate yield. Alkylation and acylation reactions occurred at the sulfur atom. Complex 3 reacted with $\mathrm{CH}_{2} \mathrm{I}_{2}$ to give the dinuclear complex $\left[\mathrm{Mo}(\mathrm{CO})_{5}\left(\mathrm{PPh}_{2} \mathrm{CS}_{2}\right)\right]_{2}\left(\mu-\mathrm{CH}_{2}\right)(\mathbf{8})$ in which the two metal atoms are bridged by the bidentate phosphorus ligand. Decarbonylation of $\mathbf{3}$ in $\mathrm{CH}_{3} \mathrm{CN}$ produced an anionic product which was identified as $\left[\mathrm{Et}_{4} \mathrm{~N}\right]\left[\mathrm{Mo}(\mathrm{CO})_{4}\left(\mathrm{PPh}_{2} \mathrm{CS}_{2}\right)\right](9)$. The $\mathrm{PPh}_{2} \mathrm{CS}_{2}^{-}$ligand of 9 bound to the metal center through both the phosphorus and one of the sulfur atoms. All of the complexes are identified by spectroscopic methods. (C) 1999 Elsevier Science S.A. All rights reserved.
\end{abstract}

Keywords: Diphenylphosphinodithioformato ligand; Molybdenum complex; Alkylation, acylation and decarbonylation reactions

\section{Introduction}

Although the dithiocarbamato ligands [1], $\mathrm{R}_{2} \mathrm{NCS}_{2}^{-}$, have attracted considerable attention, little effort has been directed toward investigating the analogous dialkylphosphinodithioformato ligands, $\mathrm{R}_{2} \mathrm{PCS}_{2}^{-}$. Until now, only a few well-characterized $\mathrm{Ph}_{2} \mathrm{PCS}_{2}^{-}$complexes of early transition metals such as $\mathrm{Zr}$ [2] and $\mathrm{W}$ [3] were reported, of which, this ligand coordinates to metal centers through the two $\mathrm{S}$ atoms or the $\mathrm{P}$ and $\mathrm{S}$ atoms by chelation, or the simple P-coordination. We were interested in the $\mathrm{Ph}_{2} \mathrm{PCS}_{2}^{-}$and $\mathrm{Ph}_{2} \mathrm{PCS}_{2} \mathrm{R}$ complexes of $\mathrm{W}(0)$ which brought about some novel chemistry such as unprecedented monodentate P-coordination mode [3a], sulfur-assisted cyclization reaction [3b], phosphine transfer reaction, $\mathrm{C}=\mathrm{S} \pi$-coordination in $\mathrm{Pd}[3 \mathrm{c}]$ and

* Corresponding author. intermolecular cyclization forming 6a-thiathiophthen [3d]. In the context of our previous studies, we extended the research to the syntheses and reactivity of molybdenum complexes with the $\mathrm{Ph}_{2} \mathrm{PCS}_{2}^{-}$ligand.

\section{Experimental}

\subsection{Materials}

All manipulations were performed under nitrogen using vacuum-line, drybox, and standard Schlenk techniques. NMR spectra were recorded on a Bruker AC200 , or on a Bruker AM-300 WB FT-NMR spectrometer and are reported in units of $\delta$ with residual protons in the solvent as an internal standard $\left(\mathrm{CDCl}_{3}, \delta\right.$ 7.24; $\mathrm{CD}_{3} \mathrm{CN}, \delta$ 1.93; $\mathrm{C}_{6} \mathrm{D}_{6}, \delta$ 7.15; $\mathrm{C}_{2} \mathrm{D}_{6} \mathrm{CO}, \delta$ 2.04). IR spectra were measured on a 
Perkin-Elmer 983 instrument and were referenced to polystyrene standard, using cells equipped with calcium fluoride windows. Mass spectra were recorded on a Jeol SX-102A spectrometer. Solvents were dried and deoxygenated by refluxing over the appropriate reagents before use. $n$-Hexane, diethyl ether, THF and benzene were distilled from sodium-benzophenone. Acetonitrile and dichloromethane were distilled from calcium hydride, and methanol from magnesium. All other solvents and reagents were of reagent grade and were used as received. $\mathrm{Mo}(\mathrm{CO})_{6}$, allyl bromide and $\mathrm{KPPh}_{2}$ were purchased from Strem, Merck and Aldrich, respectively. $\mathrm{CS}_{2}, n$-BuLi, Et ${ }_{4} \mathrm{NBr}, \mathrm{C}_{2} \mathrm{H}_{5} \mathrm{I}, \mathrm{IC}_{2} \mathrm{H}_{4} \mathrm{OH}, \mathrm{C}_{3} \mathrm{H}_{5} \mathrm{Br}$ and $\mathrm{CH}_{2} \mathrm{I}_{2}$ were purchased from Janssen. The compound $\left[\mathrm{Et}_{4} \mathrm{~N}\right]\left[\mathrm{PPh}_{2}\left(\mathrm{CS}_{2}\right)\right][3 \mathrm{e}]$ and $\mathrm{Mo}(\mathrm{CO})_{5}\left(\mathrm{PPh}_{2} \mathrm{H}\right)[3 \mathrm{f}]$ were prepared according to the literature method. Elemental analyses were carried out at the Regional Center of Analytical Instrument located at the National Taiwan University.

\subsection{Preparation of $\left[E t_{4} N\right]\left[\mathrm{Mo}(\mathrm{CO})_{5}\left(\mathrm{PPh}_{2}\right)\right](\mathbf{1})$}

To a flask containing $\mathrm{Mo}(\mathrm{CO})_{5}\left(\mathrm{PPh}_{2} \mathrm{H}\right)(0.633 \mathrm{~g}, 1.5$ $\mathrm{mmol})$ and $\mathrm{Et}_{4} \mathrm{NBr}(0.315 \mathrm{~g}, 1.5 \mathrm{mmol})$ in THF, $n$-BuLi $(1 \mathrm{ml}, 1.6 \mathrm{mmol})$ was added at $0^{\circ} \mathrm{C}$. The solution was stirred for $5 \mathrm{~min}$ and the solvent was removed under vacuum. $\mathrm{MeOH}(15 \mathrm{ml})$ was added to the flask and the solution was stored at $-18^{\circ} \mathrm{C}$ for $12 \mathrm{~h}$ to give yellow precipitates. These precipitates were filtered, washed with diethyl ether $(2 \times 10 \mathrm{ml})$ and then dried under vacuum to give $1(0.77 \mathrm{~g})$ as yellow powder in $93 \%$ yield. Spectroscopic data for 1: IR $\left(\mathrm{CH}_{2} \mathrm{CI}_{2}\right)$ : $v_{\mathrm{CO}}$ 2070(m), 1910(vs) cm ${ }^{-1} ;{ }^{1} \mathrm{H}-\mathrm{NMR}\left(\mathrm{CDCl}_{3}\right): \delta 1.18$ (tt, $\left.12 \mathrm{H}, \mathrm{CH}_{3}, J_{\mathrm{N}-\mathrm{H}}=1.87 \mathrm{~Hz}, J_{\mathrm{H}-\mathrm{H}}=7.30 \mathrm{~Hz}\right), 3.18(\mathrm{q}$, $\left.8 \mathrm{H}, \mathrm{CH}_{2}, J_{\mathrm{H}-\mathrm{H}}=7.30 \mathrm{~Hz}\right), 7.47(\mathrm{~m}, 6 \mathrm{H}, \mathrm{Ph}), 7.67(\mathrm{~m}$, $4 \mathrm{H}, \mathrm{Ph}) ;{ }^{13} \mathrm{C}-\mathrm{NMR}\left(\mathrm{CD}_{3} \mathrm{CN}\right): \delta 7.6\left(\mathrm{~s}, \mathrm{CH}_{3}\right), 52.9(\mathrm{~s}$, $\left.\mathrm{CH}_{2}\right), 128.2\left(\mathrm{~d}\right.$, meta-C of $\left.\mathrm{Ph}, J_{\mathrm{P}-\mathrm{C}}=9.0 \mathrm{~Hz}\right), 131.5(\mathrm{~s}$, para $-\mathrm{C}$ of $\mathrm{Ph}), 133.0\left(\mathrm{~d}\right.$, ortho $-\mathrm{C}$ of $\left.\mathrm{Ph}, J_{\mathrm{P}-\mathrm{C}}=9.7 \mathrm{~Hz}\right)$, 134.6 (d, ipso-C of $\left.\mathrm{Ph}, J_{\mathrm{P}-\mathrm{C}}=34.6 \mathrm{~Hz}\right), 205.7$ (d, cis-CO, $\left.J_{\mathrm{P}-\mathrm{C}}=9.8 \mathrm{~Hz}\right), 210.0\left(\mathrm{~d}, J_{\mathrm{P}-\mathrm{C}}=25.8 \mathrm{~Hz}\right.$, trans CO); MS (FAB, NBA): $m / z 681\left(M^{+}+\mathrm{Et}_{4} \mathrm{~N}\right)$; Anal. Calc. for $\mathrm{C}_{25} \mathrm{H}_{30} \mathrm{NO}_{5} \mathrm{PMo}(551.41) \mathrm{C}: 54.45, \mathrm{H}: 5.48, \mathrm{~N}$ : 2.54. Found C: $54.35, \mathrm{H}: 5.42, \mathrm{~N}: 2.25$.

\subsection{Preparation of $\left[E t_{4} \mathrm{~N}\right]\left[\mathrm{Mo}(\mathrm{CO})_{5}\left(\mathrm{PPh}_{2} \mathrm{CS}_{2}\right)\right](3)$}

Method A: a $\mathrm{CH}_{2} \mathrm{Cl}_{2}$ solution $(5 \mathrm{ml})$ of $\mathrm{Mo}(\mathrm{CO})_{5}\left(\mathrm{CH}_{3} \mathrm{CN}\right) \quad(0.277 \mathrm{~g}, 1.0 \mathrm{mmol})$ was added slowly at room temperature to a $\mathrm{CH}_{2} \mathrm{Cl}_{2}$ solution (20 $\mathrm{ml})$ of $\left[\mathrm{Et}_{4} \mathrm{~N}\right]\left[\mathrm{PPh}_{2} \mathrm{CS}_{2}\right]$ (2) (0.391 g, $\left.1.0 \mathrm{mmol}\right)$. The solution was stirred for $1 \mathrm{~h}$. The reaction was monitored by ${ }^{31} \mathrm{P}-\mathrm{NMR}$. After complete disappearance of the ${ }^{31} \mathrm{P}$ resonance of $\mathbf{2}$, dichloromethane was removed under vacuum to give red-brown powder. The crude product was recrystallized from a $1: 1 \mathrm{CH}_{2} \mathrm{CI}_{2} / \mathrm{MeOH}$ solution to give a microcrystalline complex $3(0.53 \mathrm{~g}$,
$84 \%)$. Method B: to a THF solution of $1(0.551 \mathrm{~g}, 1.0$ $\mathrm{mmol}), \mathrm{CS}_{2}(0.1 \mathrm{ml}, 1.6 \mathrm{mmol})$ was added at room temperature. The color changed from bright yellow to red immediately accompanied with the formation of some red precipitates. The solution was filtered and the precipitates were washed with $n$-hexane $(2 \times 10 \mathrm{ml})$ to give a red powder $3(0.55 \mathrm{~g})$ in $87 \%$ yield. Spectroscopic data for 3: IR (KBr): $v_{\mathrm{CO}}$ 2065(s), 1979(m), 1949(vs), 1909 (vs) $\mathrm{cm}^{-1},{ }^{31} \mathrm{P}-\mathrm{NMR}\left(\mathrm{CDCl}_{3}\right): \delta$ 69.8; H-NMR $\left(\mathrm{CDCl}_{3}\right): \delta 1.18\left(\mathrm{tt}, 12 \mathrm{H}, \mathrm{CH}_{3}, J_{\mathrm{N}-\mathrm{H}}=1.87 \mathrm{~Hz}, J_{\mathrm{H}-\mathrm{H}}=\right.$ $7.30 \mathrm{~Hz}), 3.15\left(\mathrm{q}, 8 \mathrm{H}, \mathrm{CH}_{2}, J_{\mathrm{H}-\mathrm{H}}=7.30 \mathrm{~Hz}\right), 7.35(\mathrm{~m}$, $6 \mathrm{H}, \mathrm{Ph}), 7.66(\mathrm{~m}, 4 \mathrm{H}, \mathrm{Ph}) ;{ }^{13} \mathrm{C}-\mathrm{NMR}\left(\mathrm{CD}_{3} \mathrm{CN}\right): 07.6$ $\left(\mathrm{s}, \mathrm{CH}_{3}\right), 52.9\left(\mathrm{~s}, \mathrm{CH}_{2}\right), 128.3$ (d, meta $-\mathrm{C}$ of $\mathrm{Ph}, J_{\mathrm{P}-\mathrm{C}}=$ $9.8 \mathrm{~Hz}), 129.9$ (s, para $-\mathrm{C}$ of $\mathrm{Ph}), 134.4$ (d, ortho $-\mathrm{C}$ of $\left.\mathrm{Ph}, J_{\mathrm{P}-\mathrm{C}}=9.8 \mathrm{~Hz}\right), 141.0\left(\mathrm{~d}\right.$, ipso-C of $\mathrm{Ph}, J_{\mathrm{P}-\mathrm{C}}=34.2$ $\mathrm{Hz}), 204.8\left(\mathrm{~d}\right.$, cis-CO, $\left.{ }^{2} J_{\mathrm{P}-\mathrm{C}}=7.5 \mathrm{~Hz}\right), 209.7(\mathrm{~d}$, trans $\left.\mathrm{CO}, J_{\mathrm{P}-\mathrm{C}}=25.5 \mathrm{~Hz}\right), 235.7\left(\mathrm{~s}, \mathrm{CS}_{2}\right)$; MS (FAB, NBA): $m / z 759\left(\mathrm{M}^{+}+\mathrm{Et}_{4} \mathrm{~N}\right), 703\left(\mathrm{M}^{+}+\mathrm{Et}_{4} \mathrm{~N}-2 \mathrm{CO}\right)$; Anal. Calc. for $\mathrm{C}_{26} \mathrm{H}_{30} \mathrm{NO}_{5} \mathrm{PS}_{2} \mathrm{Mo}(627.56) \mathrm{C}: 49.76, \mathrm{H}: 4.82$, $\mathrm{N}: 2.23$. Found C: 49.74, H: 4.85, N: 2.22 .

\subsection{Preparation of $\mathrm{Mo}(\mathrm{CO})_{5}\left[\mathrm{PPh}_{2}\left(\mathrm{CS}_{2} \mathrm{C}_{2} \mathrm{H}_{5}\right)\right]$ (4)}

$\mathrm{C}_{2} \mathrm{H}_{5} \mathrm{I}(0.01 \mathrm{ml}, 1.0 \mathrm{mmol})$ was added to a solution of $3(0.627 \mathrm{~g}, 1.0 \mathrm{mmol})$ in $\mathrm{CH}_{2} \mathrm{Cl}_{2}(20 \mathrm{ml})$ and the mixture was stirred at room temperature for $1 \mathrm{~min}$. The solvent was removed under vacuum and the residue was extracted with $n$-hexane $(2 \times 10 \mathrm{ml})$, and the extracts were filtered through celite. The filtrate was concentrated to ca. $5 \mathrm{ml}$ and cooled to $-18^{\circ} \mathrm{C}$ for $12 \mathrm{~h}$ to give the red crystalline product $\mathrm{Mo}(\mathrm{CO})_{5}\left[\mathrm{PPh}_{2}\left(\mathrm{CS}_{2} \mathrm{C}_{2} \mathrm{H}_{5}\right)\right]$ (4) $(0.45 \mathrm{~g}, 85 \%)$. Spectroscopic data for 4: IR $\left(\mathrm{CH}_{2} \mathrm{Cl}_{2}\right): \quad v_{\mathrm{CO}} \quad 2074(\mathrm{~m}), \quad 1940$ (vs) $\mathrm{cm}^{-1} ;{ }^{31} \mathrm{P}-\mathrm{NMR}$ $\left(\mathrm{CDCl}_{3}\right): \delta 75.6 ;{ }^{1} \mathrm{H}-\mathrm{NMR}\left(\mathrm{CDCl}_{3}\right): \delta 1.32\left(\mathrm{t}, 3 \mathrm{H}, \mathrm{CH}_{3}\right.$, $\left.J_{\mathrm{H}-\mathrm{H}}=7.50 \mathrm{~Hz}\right), 3.29\left(\mathrm{q}, 2 \mathrm{H}, \mathrm{CH}_{2} J_{\mathrm{H}-\mathrm{H}}=7.50 \mathrm{~Hz}\right), 7$ $47(\mathrm{~m}, 6 \mathrm{H}, \mathrm{Ph}), 7.67(\mathrm{~m}, 4 \mathrm{H}, \mathrm{Ph}) ;{ }^{13} \mathrm{C}-\mathrm{NMR}\left(\mathrm{CDCl}_{3}\right)$ : $\delta 11.8\left(\mathrm{~s}, \mathrm{CH}_{3}\right), 32.0\left(\mathrm{~s}, \mathrm{CH}_{2}\right), 128.4(\mathrm{~d}$, meta $-\mathrm{C}$ of $\mathrm{Ph}$, $\left.{ }^{3} J_{\mathrm{P}-\mathrm{C}}=9.6 \mathrm{~Hz}\right), 130.8(\mathrm{~s}$, para $-\mathrm{C}$ of $\mathrm{Ph}), 133.6(\mathrm{~d}$, ortho-C of $\left.\mathrm{Ph},{ }^{2} \mathrm{~J}_{\mathrm{P}-\mathrm{C}}=12.4 \mathrm{~Hz}\right), 134.1$ (d, ipso-C of $\mathrm{Ph}$, $\left.J_{\mathrm{P}-\mathrm{C}}=31.9 \mathrm{~Hz}\right), 205.4\left(\mathrm{~d}\right.$, cis- $\left.\mathrm{CO}, J_{\mathrm{P}-\mathrm{C}}=8.3 \mathrm{~Hz}\right), 210.1$ $\left(\mathrm{d}\right.$, trans $\left.-\mathrm{CO}, J_{\mathrm{P}-\mathrm{C}}=26.3 \mathrm{~Hz}\right), 238.9\left(\mathrm{~d}, J_{\mathrm{P}-\mathrm{C}}=4.8 \mathrm{~Hz}\right.$, $\mathrm{CS}_{2}$ ); $\mathrm{MS}$ (FAB, NBA): $m / z 528\left(\mathrm{M}^{+}\right), 499\left(\mathrm{M}^{+}-\right.$ $\left.\mathrm{C}_{2} \mathrm{H}_{5}\right), 471\left(\mathrm{M}^{+}-\mathrm{C}_{2} \mathrm{H}_{5}-\mathrm{CO}\right), 443\left(\mathrm{M}^{+}-\mathrm{C}_{2} \mathrm{H}_{5}-\right.$ 2CO), $\quad 415 \quad\left(\mathrm{M}^{+}-\mathrm{C}_{2} \mathrm{H}_{5}-3 \mathrm{CO}\right), \quad 387$ $\left(\mathrm{M}^{+}-\mathrm{C}_{2} \mathrm{H}_{5}-4 \mathrm{CO}\right), 359\left(\mathrm{M}^{+}-\mathrm{C}_{2} \mathrm{H}_{5}-5 \mathrm{CO}\right)$. Anal. Calc. for $\mathrm{C}_{20} \mathrm{H}_{15} \mathrm{O}_{5} \mathrm{PS}_{2} \mathrm{Mo}$ (526.37) C: 45.63, H: 2.87 . Found C: 45.60, H: 2.85.

\subsection{Preparation of $\mathrm{Mo}(\mathrm{CO})_{5}\left[\mathrm{PPh}_{2}\left(\mathrm{CS}_{2} \mathrm{C}_{2} \mathrm{H}_{4} \mathrm{OH}\right)\right]$ (5)}

The synthesis and work-up were similar to those used in the preparation of complex 4. The pure complex $\mathrm{Mo}(\mathrm{CO})_{5}\left[\mathrm{PPh}_{2}\left(\mathrm{CS}_{2} \mathrm{C}_{2} \mathrm{H}_{4} \mathrm{OH}\right)\right](5)$ as the red microcrystalline solid was isolated in $90 \%$ yield. Spectroscopic data for 5: IR $\left(\mathrm{CH}_{2} \mathrm{CI}_{2}\right): v_{\mathrm{CO}} 2073(\mathrm{~m}), 1984(\mathrm{~m})$, 1943(vs) $\mathrm{cm}^{-1} ;{ }^{31} \mathrm{P}-\mathrm{NMR}\left(\mathrm{CDCl}_{3}\right): \delta$ 77.4; ${ }^{1} \mathrm{H}-\mathrm{NMR}$ 
$\left(\mathrm{CDCl}_{3}\right): \delta 3.30\left(\mathrm{t}, 2 \mathrm{H}, \mathrm{SCH}_{2}, J_{\mathrm{H}-\mathrm{H}}=6.12 \mathrm{~Hz}\right), 3.53(\mathrm{t}$, $\left.2 \mathrm{H}, \mathrm{CH}_{2} \mathrm{OH}, J_{\mathrm{H}-\mathrm{H}}=6.12 \mathrm{~Hz}\right), 7.46(\mathrm{~m}, 6 \mathrm{H}, \mathrm{Ph}), 7.64$ $(\mathrm{m}, 4 \mathrm{H}, \mathrm{Ph}) ;{ }^{13} \mathrm{C}-\mathrm{NMR}\left(\mathrm{CDCl}_{3}\right): \delta 39.9\left(\mathrm{~s}, \mathrm{SCH}_{2}\right), 59.8$ (s, $\left.\mathrm{CH}_{2} \mathrm{OH}\right), 128.5\left(\mathrm{~d}\right.$, meta $-\mathrm{C}$ of $\mathrm{Ph}, J_{\mathrm{P}-\mathrm{C}}=13.5 \mathrm{~Hz}$ ), 131.1 (s, para-C of $\mathrm{Ph}$ ), 133.8 (d, ortho $-\mathrm{C}$ of $\mathrm{Ph}$, $\left.J_{\mathrm{P}-\mathrm{C}}=17.3 \mathrm{~Hz}\right), 134.3\left(\mathrm{~d}\right.$, ipso $-\mathrm{C}$ of $\mathrm{Ph}, J_{\mathrm{P}-\mathrm{C}}=38.8$ $\mathrm{Hz}), 205.4\left(\mathrm{~d}\right.$, cis $\left.-\mathrm{CO}, J_{\mathrm{P}-\mathrm{C}}=9.1 \mathrm{~Hz}\right) ; 239.7\left(\mathrm{~s}, \mathrm{CS}_{2}\right)$; MS (FAB, NBA): $m / z 544\left(\mathrm{M}^{+}\right), 516\left(\mathrm{M}^{+}-\mathrm{CO}\right), 460$ $\left(\mathrm{M}^{+}-3 \mathrm{CO}\right), 432\left(\mathrm{M}^{+}-4 \mathrm{CO}\right), 404\left(\mathrm{M}^{+}-5 \mathrm{CO}\right)$. Anal. Calc. for $\mathrm{C}_{20} \mathrm{H}_{15} \mathrm{O}_{6} \mathrm{PS}_{2} \mathrm{Mo}(542.37) \mathrm{C}: 44.29, \mathrm{H}$ : 2.79. Found C: $44.25, \mathrm{H}: 2.85$.

\subsection{Preparation of $\mathrm{Mo}(\mathrm{CO})_{5}\left[\mathrm{PPh}_{2}\left(\mathrm{CS}_{2} \mathrm{C}_{3} \mathrm{H}_{5}\right)\right]$ (6)}

The synthesis and work-up were similar to those used in the preparation of complex 4. The pure complex $\mathrm{Mo}(\mathrm{CO})_{5}\left[\mathrm{PPh}_{2}\left(\mathrm{CS}_{2} \mathrm{C}_{3} \mathrm{H}_{5}\right)\right]$ (6) as the red microcrystalline solid was isolated in $85 \%$ yield. Spectroscopic data for 6: IR $\left(\mathrm{CH}_{2} \mathrm{CI}_{2}\right)$ : $v_{\mathrm{CO}} 2073(\mathrm{~m}), \quad 1985(\mathrm{~m})$, 1946(vs) $\mathrm{cm}^{-1} ;{ }^{31} \mathrm{P}-\mathrm{NMR}\left(\mathrm{CDCl}_{3}\right): \delta 76.0 ;{ }^{1} \mathrm{H}-\mathrm{NMR}$ $\left(\mathrm{CDCl}_{3}\right): \delta 3.93\left(\mathrm{~d}, 2 \mathrm{H}, \mathrm{SCH}_{2}, J_{\mathrm{H}-\mathrm{H}}=699 \mathrm{~Hz}\right), 5.18$, $5.28\left(\mathrm{~d}, 2 \mathrm{H},=\mathrm{CH}_{2}, J_{\mathrm{H}-\mathrm{H}}=999 \mathrm{~Hz}\right), 5.78(\mathrm{~m}, 1 \mathrm{H}$, $\mathrm{CH}=), 7.46(\mathrm{~m}, 6 \mathrm{H}, \mathrm{Ph}), 7.67(\mathrm{~m}, 4 \mathrm{H}, \mathrm{Ph}) ;{ }^{13} \mathrm{C}-\mathrm{NMR}$ $\left(\mathrm{CDCl}_{3}\right): 041.5\left(\mathrm{~s}, \mathrm{SCH}_{2}\right), 120.5(\mathrm{~s}, \mathrm{CH}=), 128.5$ (d, meta-C of $\left.\mathrm{Ph}, J_{\mathrm{P}-\mathrm{C}}=9.8 \mathrm{~Hz}\right), 129.6\left(\mathrm{~s},=\mathrm{CH}_{2}\right), 130.8$ (s, para $-\mathrm{C}$ of $\mathrm{Ph}$ ), 133.7 (d, ortho $-\mathrm{C}$ of $\mathrm{Ph}, J_{\mathrm{P}-\mathrm{C}}=12.4$ $\mathrm{Hz}), 134.9$ (d, ipso-C of Ph, $\left.J_{\mathrm{P}-\mathrm{C}}=38.8 \mathrm{~Hz}\right), 205.4(\mathrm{~d}$, cis-CO, $\left.J_{\mathrm{P}-\mathrm{C}}=8.4 \mathrm{~Hz}\right), 210.0\left(\mathrm{~d}\right.$, trans $-\mathrm{CO}, J_{\mathrm{P}-\mathrm{C}}=25.5$ $\mathrm{Hz}), 238.2$ (s, $\left.\mathrm{CS}_{2}\right)$; MS (FAB, NBA): $m / z 540\left(\mathrm{M}^{+}\right)$, $512\left(\mathrm{M}^{+}-\mathrm{CO}\right), 456\left(\mathrm{M}^{+}-3 \mathrm{CO}\right), 428\left(\mathrm{M}^{+}-4 \mathrm{CO}\right)$, $400\left(\mathrm{M}^{+}-\mathrm{SCO}\right), 359\left(\mathrm{M}^{+}-5 \mathrm{CO}-\mathrm{C}_{3} \mathrm{H}_{5}\right)$. Anal. Calc. for $\mathrm{C}_{21} \mathrm{H}_{15} \mathrm{O}_{5} \mathrm{PS}_{2} \mathrm{Mo}(538.38) \mathrm{C}: 46.85, \mathrm{H}: 2.81$. Found C: 46.82, H: 2.87.

\subsection{Preparation of $\mathrm{Mo}(\mathrm{CO})_{5}\left[\mathrm{PPh}_{2}\left(\mathrm{CS}_{2} \mathrm{OCC}_{10} \mathrm{H}_{7}\right)\right]$ (7)}

The synthesis and work-up were similar to those used in the preparation of complex 4. The pure complex $\mathrm{Mo}(\mathrm{CO})_{5}\left[\mathrm{PPh}_{2}\left(\mathrm{CS}_{2} \mathrm{OCC}_{10} \mathrm{H}_{7}\right)\right](7)$ as the red microcrystalline solid was isolated in $46 \%$ yield. Complex 7 is air and moisture sensitive and elemental analysis was not obtained. Spectroscopic data for 7: IR $\left(\mathrm{CH}_{2} \mathrm{Cl}_{2}\right): v_{\mathrm{CO}}$ 2073(m), 1976(m), 1943(vs), 1726(vs) $\mathrm{cm}^{-1} ;{ }^{13} \mathrm{P}-\mathrm{NMR}$ $\left(\mathrm{CDCl}_{3}\right): \delta 775 ;{ }^{1} \mathrm{H}-\mathrm{NMR}\left(\mathrm{CDCl}_{3}\right): \delta 7.46-7.67(\mathrm{~m}$, $17 \mathrm{H}, \mathrm{Ph}) ;{ }^{13} \mathrm{C}-\mathrm{NMR}\left(\mathrm{CDCl}_{3}\right): \delta 128.5-134.9(\mathrm{~m}, \mathrm{C}$ of $\mathrm{Ph}), 170.0(\mathrm{~s}, \mathrm{SCO}), 207.4\left(\mathrm{~d}\right.$, cis-CO, $\left.J_{\mathrm{P}-\mathrm{C}}=8.4 \mathrm{~Hz}\right)$, $211.0\left(\mathrm{~d}\right.$, trans $\left.-\mathrm{CO}, J_{\mathrm{P}-\mathrm{C}}=25.5 \mathrm{~Hz}\right), 238.4\left(\mathrm{~s}, \mathrm{CS}_{2}\right)$; MS (FAB, NBA): $m / z 654\left(\mathrm{M}^{+}\right)$.

\subsection{Preparation of $\left[\mathrm{Mo}(\mathrm{CO})_{5}\left(\mathrm{PPh}_{2} \mathrm{CS}_{2}\right)\right]_{2}\left(\mu-\mathrm{CH}_{2}\right)(\boldsymbol{8})$}

$\mathrm{CH}_{2} \mathrm{I}_{2}(0.1 \mathrm{ml}, 3.0 \mathrm{mmol})$ was added slowly to a solution of $3(0.627 \mathrm{~g}, 1.0 \mathrm{mmol})$ in $20 \mathrm{ml}$ of $\mathrm{CH}_{2} \mathrm{Cl}_{2}$ at room temperature and the solution was stirred for 5 min. The solvent was removed under vacuum and the residue was extracted with $n$-hexane $(2 \times 10 \mathrm{ml})$, and the extract was filtered through celite. The filtrate was concentrated to $5 \mathrm{ml}$ and stored at $-18^{\circ} \mathrm{C}$ for $12 \mathrm{~h}$ to give the red-brown crystalline product $\left[\mathrm{Mo}(\mathrm{CO})_{5}\left(\mathrm{PPh}_{2} \mathrm{CS}_{2}\right)\right]_{2}\left(\mu-\mathrm{CH}_{2}\right)(\mathbf{8})(0.41 \mathrm{~g}, 82 \%)$. Spectroscopic data for 8: IR $\left(\mathrm{CH}_{2} \mathrm{Cl}_{2}\right): v_{\mathrm{CO}}$ 2074(m), 1985(m), 1945(vs) $\mathrm{cm}^{-1} ;{ }^{31} \mathrm{P}-\mathrm{NMR}\left(\mathrm{CDCl}_{3}\right): \delta 77.0$; ${ }^{1} \mathrm{H}-\mathrm{NMR}\left(\mathrm{CDCl}_{3}\right): \delta 4.99\left(\mathrm{~s}, 2 \mathrm{H}, \mathrm{CH}_{2}\right), 7.40-7.66(\mathrm{~m}$, $20 \mathrm{H}, \mathrm{Ph}) ;{ }^{13} \mathrm{C}-\mathrm{NMR}\left(\mathrm{CDCl}_{3}\right): \delta 42.4\left(\mathrm{~s}, \mathrm{CH}_{2}\right), 128.5(\mathrm{~d}$, meta $-\mathrm{C}$ of $\left.\mathrm{Ph}, J_{\mathrm{P}-\mathrm{C}}=8.3 \mathrm{~Hz}\right), 131.3(\mathrm{~s}$, para $-\mathrm{C}$ of $\mathrm{Ph})$, $133.6\left(\mathrm{~d}\right.$, ortho $-\mathrm{C}$ of $\left.\mathrm{Ph}, J_{\mathrm{P}-\mathrm{C}}=11.8 \mathrm{~Hz}\right), 134.3(\mathrm{~d}$, ipso-C of Ph, $\left.J_{\mathrm{P}-\mathrm{C}}=46.0 \mathrm{~Hz}\right), 205.2\left(\mathrm{~d}\right.$, cis $-\mathrm{CO}, J_{\mathrm{P}-\mathrm{C}}=$ $6.5 \mathrm{~Hz}), 209.2\left(\mathrm{~d}\right.$, trans $\left.-\mathrm{CO}, J_{\mathrm{P}-\mathrm{C}}=25.5 \mathrm{~Hz}\right), 237.6(\mathrm{~s}$, $\left.\mathrm{CS}_{2}\right)$; MS (FBA, NBA): $m / z 1010\left(\mathrm{M}^{+}\right), 786\left(\mathrm{M}^{+}\right.$ $-8 \mathrm{CO}), 758\left(\mathrm{M}^{+}-9 \mathrm{CO}\right), 730\left(\mathrm{M}^{+}-10 \mathrm{CO}\right)$; Anal. Calc. for $\mathrm{C}_{37} \mathrm{H}_{22} \mathrm{O}_{10} \mathrm{P}_{2} \mathrm{~S}_{4} \mathrm{Mo}_{2}(1008$ 65) $\mathrm{C}: 44.06, \mathrm{H}$ : 2.20. Found $\mathrm{C}: 44.00, \mathrm{H} 2.27$.

\subsection{Preparation of $\left[E t_{4} \mathrm{~N}\right]\left[\mathrm{Mo}(\mathrm{CO})_{4}\left(\mathrm{PPh}_{2} \mathrm{CS}_{2}\right)\right]$ (9)}

Compound $3(0.627 \mathrm{~g}, 1.0 \mathrm{mmol})$ was dissolved in 10 $\mathrm{ml}$ of $\mathrm{CH}_{3} \mathrm{CN}$. The solution was stirred at room temperature and the reaction monitored by IR spectra. After stirring for $10 \mathrm{~min}$, and IR spectrum indicated that the starting material was completely consumed. The solution was cooled and the solvent was removed in vacuum. Recrystallization using a cold 1:1 $n$-hexane/ $\mathrm{CH}_{2} \mathrm{CI}_{2}$ to give the red crystalline product $9(0.42 \mathrm{~g}$, $70 \%$ ). Spectroscopic data for 9: IR $\left(\mathrm{CH}_{2} \mathrm{Cl}_{2}\right)$ : $v_{\mathrm{CO}}$ 2009(m), 1893(vs), 1865(sh), 1827(s) $\mathrm{cm}^{-1} ;{ }^{31} \mathrm{P}-\mathrm{NMR}$ $\left(\mathrm{CDCl}_{3}\right): \delta 38.9 ;{ }^{1} \mathrm{H}-\mathrm{NMR}\left(\mathrm{CDCl}_{3}\right): \delta 1.18(\mathrm{tt}, 12 \mathrm{H}$, $\left.\mathrm{CH}_{3}, \quad J_{\mathrm{N}-\mathrm{H}}=1.87, \quad J_{\mathrm{H}-\mathrm{H}}=7.30 \mathrm{~Hz}\right), 3.15(\mathrm{q}, 8 \mathrm{H}$, $\left.\mathrm{NCH}_{2}, J_{\mathrm{H}-\mathrm{H}}=7.30 \mathrm{~Hz}\right), 7.47(\mathrm{~m}, 6 \mathrm{H}, \mathrm{Ph}), 7.69(\mathrm{~m}, 4 \mathrm{H}$, $\mathrm{Ph}) ;{ }^{13} \mathrm{C}-\mathrm{NMR}\left(\mathrm{CDCl}_{3}\right): \delta 7.6\left(\mathrm{~s}, \mathrm{CH}_{3}\right), 52.9\left(\mathrm{~s}, \mathrm{NCH}_{2}\right)$, $129.0\left(\mathrm{~d}\right.$, meta $-\mathrm{C}$ of $\left.\mathrm{Ph}, J_{\mathrm{P}-\mathrm{C}}=8.3 \mathrm{~Hz}\right), 130.9$ (s, para $-\mathrm{C}$ of $\mathrm{Ph}$ ), 133.8 (d, ortho-C of $\left.\mathrm{Ph}, J_{\mathrm{P}-\mathrm{C}}=14.6 \mathrm{~Hz}\right), 136.5$ (d, ipso-C of $\mathrm{Ph}, J_{\mathrm{P}-\mathrm{C}}=21.8 \mathrm{~Hz}$ ), 211.0, 212.2 (cis$\mathrm{CO}), 222.7\left(\mathrm{~d}\right.$, trans $\left.-\mathrm{CO}, J_{\mathrm{P}-\mathrm{C}}=28.9 \mathrm{~Hz}\right), 238.1(\mathrm{~s}$, $\left.\mathrm{CS}_{2}\right)$; MS (FAB, NBA): $m / z 731\left(\mathrm{M}^{+}+\mathrm{Et}_{4} \mathrm{~N}\right), 703$ $\left(\mathrm{M}^{+}+\mathrm{Et}_{4} \mathrm{~N}-\mathrm{CO}\right)$; Anal. Calc. for $\mathrm{C}_{25} \mathrm{H}_{30} \mathrm{NO}_{4} \mathrm{PS}_{2} \mathrm{Mo}$ (599.55) C: 50.08, H: 5.04, N: 2.34. Found C: 50.15, H: $5.20, \mathrm{~N}: 2.14$.

\section{Results and discussion}

\subsection{Synthesis of the anionic complex $\left[\mathrm{Et}_{4} \mathrm{~N}\right]\left[\mathrm{Mo}(\mathrm{CO})_{5}\left(\mathrm{PPh}_{2} \mathrm{CS}_{2}\right)\right](\mathbf{3})$}

Abstraction of a proton from the metal coordinated phosphine has been reported for the synthesis of the phosphorus derivatives [4]. Interestingly, up to now, only a few examples are known for dialkylphosphinodithioformato ligand, $\mathrm{R}_{2} \mathrm{PCS}_{2}^{-}$. These $\mathrm{R}_{2} \mathrm{PCS}_{2}^{-}$ ligands are probably air-sensitive and oxidized easily to give $\mathrm{R}_{2} \mathrm{P}(\mathrm{X}) \mathrm{CS}_{2}(\mathrm{X}=\mathrm{O}, \mathrm{S})$. 


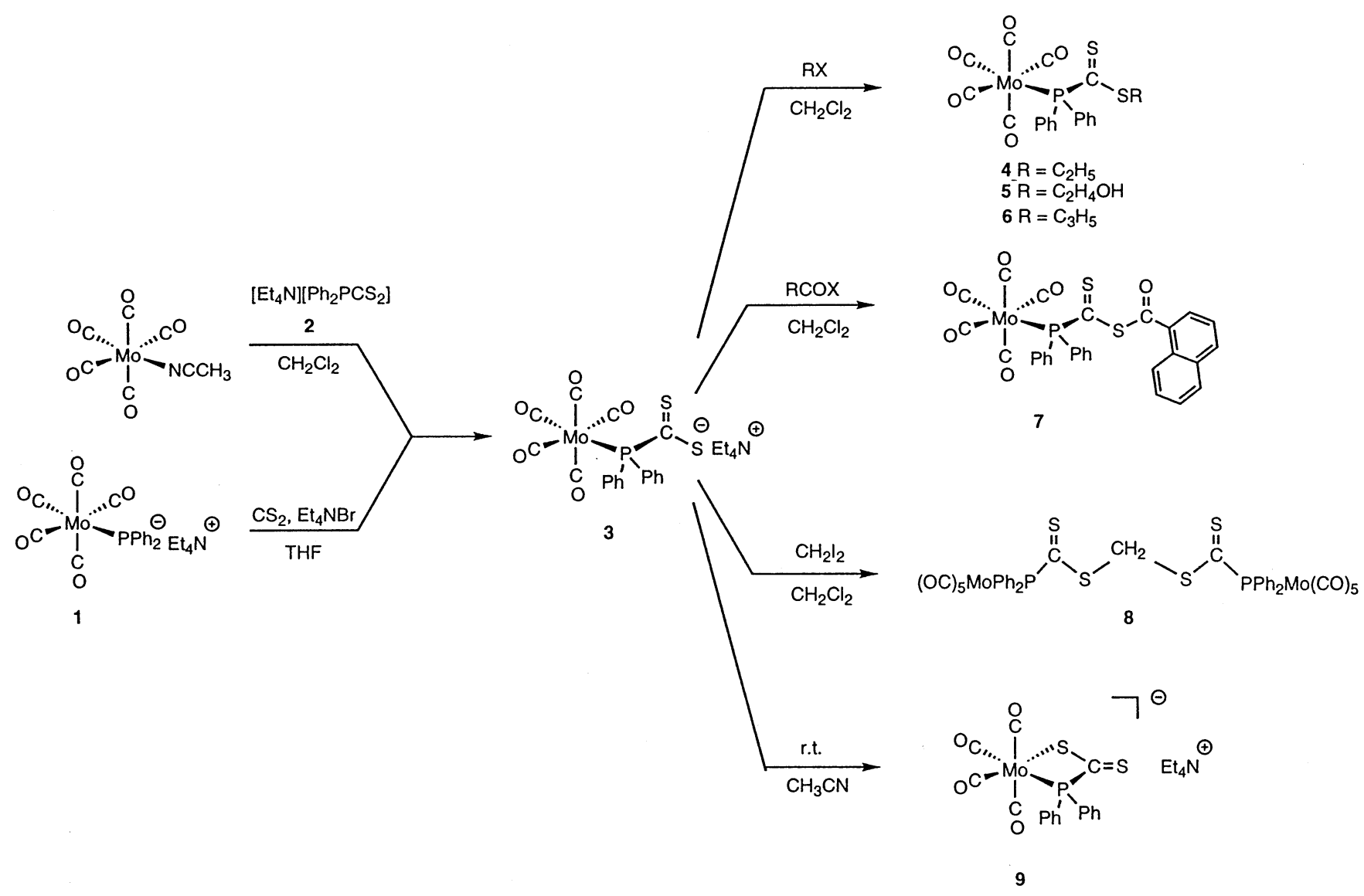

Scheme 1.

Complex $\left[\mathrm{Et}_{4} \mathrm{~N}\right]\left[\mathrm{Mo}(\mathrm{CO})_{5}\left(\mathrm{PPh}_{2}\right)\right](\mathbf{1})$ was produced in high yield by the reaction of $\mathrm{Mo}(\mathrm{CO})_{5}\left(\mathrm{HPPh}_{2}\right)$ with $n$-BuLi in diethyl ether $\left(-78^{\circ} \mathrm{C}\right)$ in the presence of $\mathrm{Et}_{4} \mathrm{NBr}$. The slightly air-sensitive yellow compound $\mathbf{1}$ is soluble in $\mathrm{CH}_{2} \mathrm{Cl}_{2}$ and $\mathrm{CH}_{3} \mathrm{CN}$ and insoluble in $n$-hexane and diethyl ether. The ${ }^{13} \mathrm{C}-\mathrm{NMR}$ of 1 reveals two resonances at $\delta 205.7$ and 210.0 with a $4: 1$ ratio, which are assigned to the carbon atoms of the cis and trans carbonyl groups, respectively. Complex $\left[\mathrm{Et}_{4} \mathrm{~N}\right][\mathrm{Mo}-$ $\left.(\mathrm{CO})_{5}\left(\mathrm{PPh}_{2} \mathrm{CS}_{2}\right)\right]$ (3) can be obtained by two routes (Scheme 1). Both treatment of 1 with $\mathrm{CS}_{2}$ and the reaction of $\mathrm{Mo}(\mathrm{CO})_{5}\left(\mathrm{CH}_{3} \mathrm{CN}\right)$ with $\left[\mathrm{Et}_{4} \mathrm{~N}\right]\left[\mathrm{PPh}_{2} \mathrm{CS}_{2}\right]$ (2) lead to the formation of $\mathbf{3}$ in 87 and $84 \%$ yield, respectively. The red complex $\mathbf{3}$ is stable in solid-state and undergoes decarbonylation reaction in solution (described below). The analytical data of $\mathbf{3}$ are in agreement with the formula. FAB mass spectrum of $\mathbf{3}$ shows a base peak with a typical Mo isotope pattern corresponding to the $\left[\mathrm{M}^{+}+\mathrm{Et}_{4} \mathrm{~N}\right]$ molecular mass. The IR spectrum of 3 shows three terminal carbonyl stretchings $\left(2 \mathrm{~A}_{1}+\mathrm{E}\right)$ that reveal a typical pattern for a $\mathrm{LM}(\mathrm{CO})_{5}$ unit with an octahedral geometry. Down-field shift of the ${ }^{31} \mathrm{P}$ resonance of $\mathbf{3}(\delta 69.8)$ relative to that of $\mathbf{1}$ indicates formation of the $\mathrm{Ph}_{2} \mathrm{PCS}_{2}^{-}$ligand and transfer of electron density from the phosphorus atom to the $\mathrm{CS}_{2}$ portion. The ${ }^{13} \mathrm{C}-\mathrm{NMR}$ of $\mathbf{3}$ reveals three reso- nances at $\delta 204.8\left(J_{\mathrm{P}-\mathrm{C}}=7.5 \mathrm{~Hz}\right), 209.3\left(J_{\mathrm{P}-\mathrm{C}}=25.5\right.$ $\mathrm{Hz}$ ) and 235.7 assignable to the carbon atoms of the $c i s$ carbonyl groups and the trans carbonyl group and the carbon disulfide, respectively.

Kunze, Ambrosius and co-workers [5] have synthesized the anionic heteroallyl ligands containing phosphorus such as $\mathrm{R}_{2} \mathrm{P}(\mathrm{X}) \mathrm{C}(\mathrm{Y}) \mathrm{NR}^{-}$or $\mathrm{R}_{2} \mathrm{PC}(\mathrm{Y}) \mathrm{NR}^{-}$ $(\mathrm{X}=\mathrm{O}$ or $\mathrm{S}, \mathrm{Y}=\mathrm{O}$ or $\mathrm{S})$. Notably, all of these anionic heteroallyl ligands bound to transition metals through $\mathrm{O}$ and $\mathrm{S}$ [5a], $\mathrm{N}$ and $\mathrm{S}$ [5c,d], $\mathrm{S}$ and $\mathrm{S}$ [5e], $\mathrm{P}$ and $\mathrm{S}$ [5b,d, f-i] and no mono-dentate phosphorus coordination has been observed. Obviously, 3 is formed via abstraction of a proton by $n-\mathrm{BuLi}$, followed by the addition of the resulting phosphido unit onto the carbon atom of $\mathrm{CS}_{2}$. In 1987, Hey and co-workers reported the insertion reaction of $\mathrm{CS}_{2}$ into a $\mathrm{Zr}-\mathrm{P}$ [2] bond, forming the dialkylphosphinodithioformato ligand, $\mathrm{R}_{2} \mathrm{PCS}_{2}^{-}$. The bis(trimethylsily)phosphino zirconium complex $\left[\mathrm{Zr}\left(\eta^{5}-\mathrm{C}_{5} \mathrm{H}_{5}\right)_{2}\left\{\eta^{2}-\mathrm{S}_{2} \mathrm{CP}\left(\mathrm{SiMe}_{3}\right)_{2}\right\} \mathrm{Cl}\right]$, obtained from the reaction of $\left[\mathrm{Zr}\left(\eta^{5}-\mathrm{C}_{5} \mathrm{H}_{5}\right)_{2}\left(\mathrm{PR}_{2}\right) \mathrm{X}\right] \mathrm{X}$ $\left(\mathrm{R}=\mathrm{SiMe}_{3}, \mathrm{X}=\mathrm{Cl}\right.$ or $\left.\mathrm{Me}\right)$ with $\mathrm{CS}_{2}$, contains a $\mathrm{R}_{2} \mathrm{PCS}_{2}^{-}$ligand chelating through the two sulfur atoms of the $\mathrm{CS}_{2}$ moiety. No insertion of $\mathrm{CS}_{2}$ into the metalphosphine bond was observed for our tungsten- and molybdenum complexes. Instead, the dithiocarbamato ligand, $\mathrm{R}_{2} \mathrm{NCS}_{2}^{-}$was synthesized by the insertion reac- 
tion of $\mathrm{CS}_{2}$ into the $\mathrm{M}-\mathrm{N}$ bond $(\mathrm{M}=\mathrm{Cr}, \mathrm{Mo}, \mathrm{W})$ [6b]. The fact that the formation of $\mathbf{3}$ was observed in two different synthetic routes clearly indicates that $\mathbf{3}$ is a thermodynamic product and the P-coordination seems to be more favorable than the S-coordination for the $\mathrm{Ph}_{2} \mathrm{PCS}_{2}^{-}$ligand.

\subsection{Alkylation and acylation of $\left[\mathrm{Et}_{4} \mathrm{~N}\right]\left[\mathrm{Mo}(\mathrm{CO})_{5}\left(\mathrm{PPh}_{2} \mathrm{CS}_{2}\right)\right]$ (3)}

To explore the reactivity of complex $\mathbf{3}$, we carried out the reactions of 3 with several alkyl halides and acyl halide. The reaction of 3 with $\mathrm{C}_{2} \mathrm{H}_{5} \mathrm{I}$ in $\mathrm{CH}_{2} \mathrm{Cl}_{2}$ gave the neutral complex $\mathrm{Mo}(\mathrm{CO})_{5}\left[\mathrm{PPh}_{2}\left(\mathrm{CS}_{2} \mathrm{C}_{2} \mathrm{H}_{5}\right)\right](4)$. This red powder was isolated in $85 \%$ yield. Extraction with $n$-hexane followed by removal of the solvent gave the analytically pure product $\mathbf{4}$. Complex $\mathbf{4}$ is stable in refluxing $\mathrm{CH}_{3} \mathrm{CN}$ or $\mathrm{C}_{6} \mathrm{H}_{6}$ under $\mathrm{N}_{2}$. The FAB mass spectrum of 4 shows a base peak in agreement with the $\left[\mathrm{M}^{+}\right]$ion fragment. The ${ }^{1} \mathrm{H}-\mathrm{NMR}$ spectrum of 4 exhibits two resonances at $\delta 1.32$ and 3.29 with a $3: 2$ ratio attributed to the ethyl protons and the corresponding resonances in the ${ }^{13} \mathrm{C}$-NMR spectrum appear at $\delta 11.8$ and 32.0 , respectively. The ${ }^{31} \mathrm{P}-\mathrm{NMR}$ spectrum of $\mathbf{4}$ shows a resonance at $\delta 75.6$, close to that of 3. On the basis of these spectroscopic data, it is likely that the alkylation takes place at one of the sulfur atom. This result is consistent with that of the analogue complex $\mathrm{W}(\mathrm{CO})_{5}\left[\mathrm{PPh}_{2}\left(\mathrm{CS}_{2} \mathrm{Me}\right)\right]$ [3c], which was structurally confirmed by an X-ray diffraction analysis. The other alkylated complexes $\mathrm{Mo}(\mathrm{CO})_{5}\left[\mathrm{PPh}_{2}\left(\mathrm{CS}_{2} \mathrm{R}\right)\right] \quad(\mathrm{R}=$ $\mathrm{C}_{2} \mathrm{H}_{4} \mathrm{OH}, 5 ; \mathrm{C}_{3} \mathrm{H}_{5} ; 6$ ) have been prepared in a similar way. In the mass spectra of $\mathbf{5}$ and $\mathbf{6}$, the molecular ion along with the $\left[\mathrm{M}^{+}-\mathrm{CO}\right]$ peak are detected. The ${ }^{13} \mathrm{C}$-NMR spectra of $\mathbf{5}$ and $\mathbf{6}$ both reveal singlet resonances at $\delta 39.9$ and 59.9 for 5 and $\delta 41.5,120.5$ and 129.6 for $\mathbf{6}$, which are assigned to the carbon atoms of the $\mathrm{SCH}_{2} \mathrm{CH}_{2} \mathrm{OH}$ and $\mathrm{SCH}_{2} \mathrm{CH}=\mathrm{CH}_{2}$ groups, respectively. By comparing the spectroscopic data of the alkylated molybdenum complexes with that of the corresponding alkylated tungsten complexes [3e], it is clear that the organic segments have the same chemical environment, namely, $S$-alkylation.

In the reaction of $\mathbf{3}$ with 1-naphthoyl chloride $\left[\mathrm{C}_{10} \mathrm{H}_{7} \mathrm{C}(\mathrm{O}) \mathrm{Cl}\right]$, complex 7 was obtained. The lower yield of this green complex relative to the higher yields of the alkylation products may result from its air- and moisture-sensitive character. The IR absorption of the acyl group of 7 appears at $1726 \mathrm{~cm}^{-1}$ and the ${ }^{13} \mathrm{C}-\mathrm{NMR}$ resonance at $\delta 170.0$. Interestingly, chemical shifts of the ${ }^{31} \mathrm{P}$ resonances of all the alkylated and acylated complexes all fall within the region of $\delta 75-78$, indicating similar structure for all these complexes. Although the differences are small, ${ }^{31} \mathrm{P}$ chemical shift moves toward down-field region as the group attached to the phosphine ligand becoming more electron-withdrawing.
This alkylation reaction was extended for $\mathrm{CH}_{2} \mathrm{I}_{2}$ in order to synthesize dinuclear complex. The reaction of 3 with excess $\mathrm{CH}_{2} \mathrm{I}_{2}$ in $\mathrm{CH}_{2} \mathrm{Cl}_{2}$ gave the dinuclear complex $\left[\mathrm{Mo}(\mathrm{CO})_{5}\left(\mathrm{PPh}_{2} \mathrm{CS}_{2}\right)\right]_{2}\left(\mu-\mathrm{CH}_{2}\right)$ (8). The proposed monomeric complex $\mathrm{Mo}(\mathrm{CO})_{5}\left[\mathrm{PPh}_{2}\left(\mathrm{CS}_{2} \mathrm{CH}_{2} \mathrm{I}\right)\right]$ was not detected in the reaction. The ${ }^{1} \mathrm{H}-\mathrm{NMR}$ spectrum of 8 exhibits a resonance at $\delta 4.99$ assignable to the $\mathrm{CH}_{2}$ group and the corresponding ${ }^{13} \mathrm{C}-\mathrm{NMR}$ signal is at $\delta$ 42.4. The ${ }^{31} \mathrm{P}-\mathrm{NMR}$ spectrum of $\mathbf{8}$ shows a resonance at $\delta$ 77.0. The FAB mass spectrum of 8 shows a base peak at $\mathrm{m} / z 730$ corresponding to $\left[\mathrm{Mo}\left(\mathrm{PPh}_{2} \mathrm{CS}_{2}\right)\right]_{2}(\mu-$ $\mathrm{CH}_{2}$ ), formed by loss of ten $\mathrm{CO}$ groups from $\mathbf{8}$ and this phenomenon was also observed for the complex $\left[\mathrm{W}(\mathrm{Co})_{5}\left(\mathrm{PPh}_{2} \mathrm{CS}_{2}\right)\right]_{2}\left(\mu-\mathrm{CH}_{2}\right)[3 \mathrm{e}]$. On the basis of these data, it is clear that the two metal centers are connected by the $\left(\mathrm{Ph}_{2} \mathrm{PCS}_{2}\right)_{2} \mathrm{CH}_{2}$ bridge.

\subsection{Decarbonylation of $\left[E t_{4} N\right]\left[\mathrm{Mo}(\mathrm{CO})_{5}\left(\mathrm{PPh}_{2} \mathrm{CS}_{2}\right)\right](3)$}

When the $\mathrm{CH}_{3} \mathrm{CN}$ solution of 3 was stirred, decarbonylation occurred affording a stable compound which can be formulated as $\left[\mathrm{Et}_{4} \mathrm{~N}\right]\left[\mathrm{Mo}(\mathrm{CO})_{4}\left(\mathrm{PPh}_{2} \mathrm{CS}_{2}\right)\right]$ (9) based on its analytical and spectroscopic data (Scheme 1). The IR spectrum of 9 shows a pattern different from that of $\mathrm{M}(\mathrm{CO})_{5} \mathrm{~L}$. The four IR absorptions at 2009, $1893,1865,1827 \mathrm{~cm}^{-1}$, are typical for a $\mathrm{M}(\mathrm{CO})_{4}[6]$ unit with a pseudooctahedral geometry. The ${ }^{31} \mathrm{P}-\mathrm{NMR}$ spectrum of 9 shows a resonance at $\delta 38.9$. The significant up-field shift of the ${ }^{31} \mathrm{P}$ resonance of 9 relative to that of 3 ( $\delta$ 69.8) suggests a distinctively different chemical and electronic environment for the $\mathrm{R}_{2} \mathrm{PCS}_{2}^{-}$ligand which supports its structure depicted in Scheme 1. Kunze and Cotton have reported complexes with similar coordination via the $\mathrm{P}$ and $\mathrm{S}$ atoms in the hetero-allylic $\mathrm{Ph}_{2} \mathrm{PCSNR}^{-}$ligands [5]. Notably, the decarbonylation reaction of 3 occurred in acetonitrile instantly but very slowly in dichloromethane. The phenomenon probably caused by better donor ability of $\mathrm{CH}_{3} \mathrm{CN}$ than $\mathrm{CH}_{2} \mathrm{Cl}_{2}$. The acylation and alkylation reaction of $\mathbf{3}$ can also be carried out in $\mathrm{CH}_{2} \mathrm{Cl}_{2}$ and the alkylated products can be obtained in higher yield.

\section{Concluding remarks}

This study describes the chemical behavior of the anionic diphenylphosphinodithioformato $\mathrm{Mo}(0)$ complex $\left[\mathrm{Et}_{4} \mathrm{~N}\right]\left[\mathrm{Mo}(\mathrm{CO})_{5}\left(\mathrm{PPh}_{2} \mathrm{CS}_{2}\right)\right]$ (3) toward alkylation, acylation and decarbonylation reactions. By comparing with our previous study of the $\mathrm{W}$ analogues, significant differences between the Mo and W complexes in solubility, stability and nucleophilicity are observed. Notably, the decarbonylation reaction is spontaneous for Mo but requires heating for the $\mathrm{W}$ complex. The molybdenum complexes with the $\mathrm{Ph}_{2} \mathrm{PCS}_{2}^{-}$ligand are more soluble in common organic solvents than the corresponding tung- 
sten complexes but the stability of molybdenum complexes are lower and with weaker nucleophilicity.

\section{Acknowledgements}

We thank the National Science Council of Taiwan, ROC for support.

\section{References}

[1] (a) D. Coucouvanis, Prog. Inorg. Chem. 11 (1970) 233. (b) R. Colton, G.R. Scollary, I.B. Tomkins, Aust. J. Chem. 21 (1968) 15. (c) B.J. Brisdon, G.F. Griffn, J. Chem. Soc. Dalton Trans. (1975) 1999. (d) J.W. McDonald, J.L. Corbin, W.E. Newton, J. Am. Chem. Soc. 97 (1975) 1970. (e) J.L. Templeton, B.C. Ward, Inorg. Chem. 19 (1980) 1753. (f) J.L. Templeton, S.J.N. Burgmayer, Organometallics 1 (1982) 1007. (g) K.-B. Shiu, K.-H. Yih, S.-L. Wang, F.L. Liao, J. Organomet. Chem. 420 (1991) 359. (h) G.L. Hillhouse, B.L. Haymore, J. Am. Chem. Soc. 104 (1982) 1537. (i) E. Carmona, L. Contreras, L. Sanchez, J. Gutierrez-Puebla, E.A. Monga, J. Chem. Soc. Dalton Trans. (1989) 2003. (j) E.M. Armstrong, P.K. Baker, M.G.B. Drew, Organometallics 7 (1988) 319.

[2] E. Hey, M.F. Lappert, J.L. Atwood, S.G. Bott, J. Chem. Soc. Chem. Commun. (1987) 421
[3] (a) K.-H. Yih, Y.-C. Lin, M.-C. Cheng, Y. Wang, J. Chem. Soc. Chem. Commun. (1993) 1380. (b) K.-H. Yih, Y.-C. Lin, M.-C. Cheng, Y. Wang, Organometallics 13 (1994) 1561. (c) K.-H. Yih, Y.-C. Lin, M.-C. Cheng, Y. Wang, J. Organomet. Chem. 474 (1994) C34. (d) K.-H. Yih, Y.C. Lin, G.-H. Lee, Y. Wang, J. Chem. Soc. Chem. Commun. (1995) 223. (e) K.-H. Yih, Y.C. Lin, M.-C. Cheng, Y. Wang, J. Chem. Soc. Dalton Trans. (1995) 1305. (f) J. Powell, C. Couture, M.R. Gregg, J.F. Sawyer, Inorg. Chem. 28 (1989) 3437.

[4] P.M. Treichel, W.M. Donglas, W.K. Dean, Inorg. Chem. 11 (1972) 1615.

[5] (a) H.P.M.M. Ambrosius, W.P. Bosman, J.A. Gras, J. Organomet. Chem. 215 (1981) 201. (b) H.P.M.M. Ambrosius, A.H.I.M. Van Der Linden, J.J. Steggerda, J. Organomet. Chem. 204 (1980) 211. (c) H.P.M.M. Ambrosius, F.A. Cotton, L.R. Falvello, J.M.H.T. Hintzen, T.J. Melton, W. Schwotzer, M. Tomas, J.G.M. Van Der Linden, Inorg. Chem. 23 (1984) 1611. (d) H.P.M.M. Ambrosius, J. Willemse, J.A. Cras, W.P. Bosman, J.H. Noordik, Inorg. Chem. 23 (1984) 2672. (e) H.P.M.M. Ambrosius, A.W. Van Hemert, W.P. Bosman, J.H. Noordik, G.J.A. Ariaans, Inorg. Chem. 23 (1984) 2678. (f) A. Antoniadis, U. Kunze, M. Moll, J. Organomet. Chem. 235 (1982) 177. (g) U. Kunze, A. Brunsa, D. Rehder, J. Organomet. Chem. 268 (1984) 213. (h) U. Kunze, A. Bruns, J. Organomet. Chem. 292 (1985) 349. (i) U. Kunze, H. Jawad, R. Burghardt, R. Tittmann, V. Kruppa, J. Organomet. Chem. 302 (1986) C30.

[6] (a) B. Zhuang, L. Huang, L. He, Y. Yang, J. Lu, Inorg. Chim. Acta, 145 (1988) 225. (b) K.H. Yih, S.-C. Cheng, Y.-C. Lin, M.-C. Cheng, Y. Wang, J. Organomet. Chem. 494 (1995) 149. 